\title{
Expectations of stakeholders regarding home care provision in rural Namibia
}

\author{
Scholastika Ndatinda lipinge, Doctoral student, Department of Nursing,RAU \\ AC Botes, Professor, Department of Nursing, RAU
}

\section{Abstract}

As in many countries, the disease pattern in Namibia has changed, health problems are increasing and outweigh the capacity of the existing health resources. Government health facilities in Namibia have limited capacity to accommodate all sick people, especially those who are chronically and terminally ill. Many hospitals in rural Namibia are overcrowded, patients sleep on the floors and, in some cases, children share beds. Morbidities relating particularly to AIDS, chronic conditions and other physical and emotional disabilities are likely to require longterm home care. In most instances, the health system is also not prepared to provide home care, nor provide the support that is required by the caregivers of disabled, chronically sick people. To ease the burden of care felt by the state at health facilities, the Ministry of Health and Social Services in Namibia has, on several occasions, called upon the community and other stakeholders in health care to assist in caring for their loved ones at home (NBC, 1996; MOHSS, 1996).

The purpose of the study was to develop and describe a model for capacity building for quality home care in rural Namibia. This article focuses on the first phase of the bigger study, namely the expectations of stakeholders regarding home care provision in rural Namibia.

A qualitative, exploratory and descriptive case study design was used. Five cases were purposively selected and thirty stakeholders were interviewed. Data were analysed using a combination of the approaches of Tesch and Morse and Field. To ensure trustworthiness, triangulation and other measures of Lincoln and Guba were used.

The expectations were categorised into structures, process and outcome-related expectations. Stakeholders in rural Namibia appear to have dependency tendencies and still expect all resources and services to be provided by someone else, be it the government, the church, the headman and/or any other non-governmental agencies. There is a need empowerment and capacity building in the community and awareness must be created of the responsibility of the community in dealing with home care provision.

\section{Abstrak}

Soos in ander lande, het die siektepatrone in Namibia verander, gesondheidsprobleme het vermeerder en oorskrei die kapasiteit van die bestaande gesondheidshulpbronne. Openbare gesondheidsfasiliteite in Namibia het beperkte kapasiteit om veral kroniese en terminale siek pasiënte te akkommodeer. Baie hospitale in Namibia is oorvol en pasiënte slaap op die vloer en, in sommige gevalle, deel kinders beddens. Pasiënte met VIGS, kroniese siektetoestande en ander fisieke en emosionele gestremdhede vereis langtermyn tuisversorging. In die meeste gevalle is die gesondheidstelsel nie voorbereid of in staat om die nodige ondersteuning vir die versorging van siekes tuis te verleen nie. Die Minister van Gesondheid en Maatskaplike Dienste in Namibia het by meer as een geleentheid ' $n$ beroep op gemeenskappe en ander rolspelers gedoen om tuis na hulle geliefdes om te sien en sodoende die las op die staat te verminder.

Die doel met die studie is om 'n model vir kapasiteitbou vir tuissorg in Namibia te beskryf. Hierdie artikel fokus op die eerste fase van die groter studie, naamlik om die verwagtinge van die rolspelers ten opsigte van die voorsiening van tuissorg te verken en te beskryf.

'n Kwalitatiewe, verkennende en beskrywende gevallestudie-ontwerp is gebruik. Vyf gevalle is doelgerig geselekteer en onderhoude is met dertig rolspelers gevoer. Data is by wyse van 'n gekombineerde benadering van Tesch en Morse en Field geanaliseer. Triangulering en ander maatreëls van Lincoln and Guba is gebruik om vertrouenswaardigheid te verseker.

Die verwagtinge van die rolspelers is in strukture, proses and uitkomste geklassifiseer. Rolspelers in Namibia reflekteer 'n afhanlikheidsingesteldheid deurdat hulle verwag dat hulpbronne deur ander voorsien moet word, d.w.s die regering, die kerk, die hoofman en/of enige ander nie-regeringsagentskappe Daar bestaan ' $n$ behoefte aan gemeenskapsbemagtiging en kapasiteitsbou en die ontwikkeling van 'n bewustheid in die gemeenskap van sy eie verantwoordelikheid met die voorsiening van tuissorg. 


\section{Introduction and problem statement}

Home care is not a new concept. It has been practised in many countries and is especially directed to care for geriatric and mentally ill patients. It is suited to patients for whom their own home is the most supportive and therapeutic setting for care (Soldam, Karim, \& Karim, 1993). Home care refers to the health services provided by health care providers to promote and maintain the health of a patient in a home environment by mobilising the resources available in both the internal and external environments of an individual. It refers to any kind of health care or assistance with independent living given to functionally impaired, disabled or ill persons in their own homes. Home care can be seen as a structure, process and an outcome (Kane, Kane \& Eustine, 1994:70).

The purpose of the study was to develop and describe a model for capacity building for home care in rural Namibia. This article focuses on the first phase of the bigger study, namely the expectations of stakeholders with regard to home care provision in rural Namibia.

With the independence of Namibia in 1990, the government adopted a health policy that places emphasis on primary health care as a strategy to provide health care to all Namibians. The aim was to make health services easily accessible and available to all Namibians at a cost the country can afford, with emphasis on community involvement and partnership principles to ensure health care on a continuum (MOHSS/NCAP, 1990).

As in many countries, the Namibian disease pattern has changed, health problems are increasing and outweigh the capacity of the existing health resources. Government health facilities in Namibia have limited capacity to accommodate all sick people, especially those who are chronically and terminally ill. Many hospitals in rural Namibia are overcrowded with patients having to sleep on the floor and, in some cases, children share beds. Whiteside (1997) states that the health sector is generally not prepared for the effects that HIV and other contemporary health problems will have upon it, despite the increase in the number of people infected and becoming disabled in the process. As Jackson and Kerkhoven (1995) stated, cases of AIDS related ill health and other disabilities are escalating. The morbidities relating to AIDS, chronic conditions and other physical and emotional disabilities are likely to require long-term home care. In most instances, the health systems are also not prepared to provide home care nor to deliver the support that may be required by the care givers of disabled chronically sick people. To ease the burden of care felt by the state at health facilities, the Ministry of Health and Social Services in Namibia has, on several occasions, called upon communities and other stakeholders in health care to assist in caring for their loved ones at home (NBC, 1996; MOHSS/NCAP, 1996).

The community that is requested to provide home care lacks the basic facilities and preparation required for this. Patients are not adequately prepared for home care, as proper counselling is not done before patients are discharged and family members are not fully prepared to be involved and to continue the care at home (Nnamdi, 1995). In most instances, families are not involved or prepared for the discharge of stroke patients and therefore many families feel incompetent to continue nursing care at home themselves. Support systems at home and at community level are limited to family members, relatives and friends. Follow-up counselling services for the home are nonexistent in Namibia and it is thought to be worse in rural northern Namibia.

In most cases, the rural community lacks physical and social structures and is left to itself to deal with the ordeal of home care. Essential facilities are limited or virtually non-existent, including adequate water supply, proper nutrition, telephones, public transport, electricity, to mention but a few. Home visits by health care providers are not, if ever done, reliably conducted, as some stakeholders expressed in the empirical data. Nnamdi (1995) found that patient follow-up at home by most of the hospitals visited is non-existent. Patients are only given dates for the next visit/appointment and, if they do not show up, nothing further is done. This is especially so in rural Namibia. The situation is likely to worsen with the increased prevalence of HIV infections in Namibia, i.e. from five cases in 1986 to more than 40000 cases in 1997 (MOHSS/NCAP, 1996; NBC, 1997).

Despite the lack of basic facilities at community level, the Namibian health facilities now tend to discharge patients still in need of nursing care, earlier, to continue with this care at home, especially those patients with permanent and recurrent disabilities. This is evident from newspaper reports and a national radio call-in program during which communities complained about such practices (NBC, 1997).

Although family members seem to be willing to take care of their loved ones and do have some potential, skills and resources, one cannot resist wondering what expectations they have about the provision of home care.

\section{Purpose/objective}

The objective of this article is to explore and describe the expectations of the stakeholders involved in home care situations in rural Northern Namibia.

\section{Design and methods of research}

The researcher conducted a case study design using qualitative, exploratory and descriptive strategies.

\section{Population and sampling}

The study population included all the cases and stakeholders involved in home care situations in rural Namibia.

A case refers to a patient receiving home care and suffering from a disability, AIDS, cancer, a postpartum patient or a postoperative patient in his/her home environment, within the community environment.

The cases were chosen purposefully based on the epidemiological statistics of the Ministry of Health and Social Services in Namibia (MOHSS/NCAP, 1996:1). Purposive sampling (De Vos et al, 1998:198) was used to enable the researcher to obtain 
cases that could provide classical examples of home care in rural Namibia. The researcher identified five (5) cases for the study, i.e. one case for each condition, as explained in the definition of a case.

To be included in the study, the case should be living in rural northern Namibia, i.e. in one of the four northern regions, namely Oshana, Oshikoto, Omusati and Ohangwena. These regions were selected as approximately $60 \%$ of the population live there and have limited resources.

Stakeholders refers to a collection of individuals who have vested interest in the implementation and outcome of home care and who are afforded an equal opportunity and capacity to provide input into the process of home care provision. Stakeholders include the patient, family members and other relatives, professional health workers, traditional healers, traditional birth attendants, regional councillors, the staff of nongovernmental organisations involved in home care, as well as other government officials. In providing home care for one case, various stakeholders may be involved.

Snowball/networking sampling was used to identify the stakeholders involved in a case (Merriam, 1998:63; Parahoo, 1997:234). Thirty (30) stakeholders participate in the study (refer to table 1). To be included in the sample, an individual had to be living in rural Namibia, had to have been involved in the care of a case and the researcher had to have been referred to that individual by other stakeholders of the specific case. ordinators in the regions, district supervisors, social workers from hospitals, the Ministry of Lands, Resettlement and Rehabilitation, churches and the community leaders in the region.

Data were collected by means of individual and group interviews, field notes and observations. After having obtained the consent from the participants, a tape recorder was utilised during interviews to record the proceedings, ensuring that no responses were overlooked.

Individual interviews (Brink, 1996:158) were conducted with twenty-two $(n=22)$ stakeholders involved in the home care situation in rural Namibia. The researcher conducted the interviews. Table 2 displays the stakeholders that were interviewed individually.

Group interviews were conducted with those stakeholders who were not willing to grant individual interviews. Table 3 displays the stakeholders who granted group interviews.

Field notes were taken during and after interviews to describe the dynamics and situations during the process. This assisted the researcher in recalling all aspects of the interview. The tape-recorded data were transcribed verbatim so that no meaningful interview information was lost (Krueger, 1994:6). Some of these transcriptions were translated into English for the first external coder, as she was not conversant with the language in which the interviews were conducted. The second external coder speaks the language in which the interviews

\section{Table 1: Stakeholders who participated in the study}

\begin{tabular}{|l|c|}
\hline \multicolumn{1}{|c|}{ Stakeholders } & Number \\
\hline Patients & 5 \\
\hline Doctor & 1 \\
\hline Nurses & 8 \\
\hline HIV/AIDS co-ordinator & 1 \\
\hline Regional council & 1 \\
\hline Social worker & 1 \\
\hline Headman & 1 \\
\hline Voluntary counsellors & 4 \\
\hline Family caregivers & $\mathbf{8}$ \\
\hline Total & $\mathbf{3 0}$ \\
\hline
\end{tabular}

\section{Data collection}

To reach the respondents, the researcher worked through the health facilities, particularly through HIV/AIDS and TB co- were conducted.

Thirty $(n=30)$ stakeholders were interviewed for the purpose of this study. Data collection was stopped when the researcher achieved data saturation. 


\section{Data analysis}

Qualitative analysis, using open coding combined with conceptualisation, was done. Themes and categories were identified by using a combination of Tesch and Morse and Field's approaches of analysis, utilising emic and epic approach (De Vos et al, 1998:340-41).
Social Services, on behalf of all regional and local heath authorities. Verbal consent of all the participants in this study was obtained and participation was voluntary. Confidentiality and anonymity was ensured (DENOSA, 1998).

\section{Findings}

Caregivers were mainly female, including elderly persons and

\section{Table 2: Stakeholders who allowed individual interviews}

\begin{tabular}{|l|c|}
\hline \multicolumn{1}{|c|}{ Stakeholders } & Numbers \\
\hline Patients & 5 \\
\hline Doctor & 1 \\
\hline Nurses & 6 \\
\hline HIV/AIDS co-ordinator & 1 \\
\hline Regional council & 1 \\
\hline Social worker & 1 \\
\hline Headman & 1 \\
\hline Voluntary counsellor & 1 \\
\hline Mothers & 5 \\
\hline Total & 22 \\
\hline
\end{tabular}

\section{Table 3: Stakeholders who allowed group interviews}

\begin{tabular}{|l|c|c|}
\hline \multicolumn{1}{|c|}{ Types of Stakeholders } & $\begin{array}{c}\text { Number of group } \\
\text { interviews }\end{array}$ & $\begin{array}{c}\text { Total number of participants } \\
\text { per group }\end{array}$ \\
\hline Family caregivers & 1 & 3 \\
\hline Voluntary village counsellors & 1 & 3 \\
\hline Nurses & 1 & 2 \\
\hline Total & $\mathbf{3}$ & $\mathbf{n = 8}$ \\
\hline
\end{tabular}

\section{Validity and reliability (trustworthiness)}

To ensure trustworthiness, triangulation of sources and methods and peer reviewing (two external coders) (Lincoln \& Guba, 1985), were used.

\section{Ethical considerations}

Before starting with data collection, written permission to conduct this study was obtained from the Ministry of Health and children. They live in traditional houses with no proper toilet, water, electricity and cooking facilities. In most cases these people have no private transport and there is not always sufficient food available for the households.

Table 4 reflects the integrated (structure, process and outcome) expectations of the stakeholders regarding the provision of home care. The expectations were categorised based on the nursing process. 


\begin{tabular}{|c|c|}
\hline CATEGORY & SUBCATEGORIES \\
\hline Assessment and Diagnosis & $\begin{array}{l}\text { Determine the ability and capacity to identify own problems } \\
\text { as individuals, family or communities } \\
* \text { Identify the availability and capacity of support systems at } \\
\text { family and community levels } \\
* \quad \text { Identify the availability of pre-discharge education } \\
\text { programmes at health facility levels } \\
* \text { Identify training needs of caregivers } \\
* \text { Determine the ability to continue care at home } \\
* \text { Assess collaboration and communication levels between } \\
\text { stakeholders }\end{array}$ \\
\hline Planning & $\begin{array}{l}\text { - Select appropriate support systems } \\
\text { - Set goals and priorities } \\
\text { - Address poverty } \\
\text { - Plan pre-discharge programmes } \\
\text { - Planning of caring, referrals and follow-up strategies } \\
\text { - Develop training for home care providers } \\
\text { Address channels and means of communication and } \\
\text { collaboration } \\
\text { - Select strategies to motivate and empower families and } \\
\text { communities in self-help activities }\end{array}$ \\
\hline Implementation & $\begin{array}{l}\text { - Community/family mobilisation for solidarity and self-help } \\
\text { activities (IGA) } \\
* \text { Mobilise local and national support systems } \\
* \text { Encourage/solicit spiritual support } \\
\text { * Covide palliative care } \\
* \text { Identify coping mechanisms } \\
\text { - Collaboration and communication channels and means } \\
\text { among stakeholders } \\
* \text { Community education and information sharing strategies } \\
* \text { Organising the health care providers at village level } \\
* \text { Health promotion activities } \\
* \text { Utilisation of available local resources } \\
* \text { Recreational activities, day care centres } \\
* \text { Medication administration and compliance } \\
* \text { Home visiting programmes }\end{array}$ \\
\hline Evaluation & $\begin{array}{l}\quad \text { Self-care activities and self-reliance } \\
\quad \text { Positive coping mechanisms } \\
\therefore \quad \text { Increased knowledge of home care } \\
\therefore \quad \text { Providers both at home and at health facilities }\end{array}$ \\
\hline
\end{tabular}




\section{Assessment and diagnosis}

In the assessment and diagnosis section, expectations are related to determining what is available through a situation analysis of various home environments. This assessment is necessary to enable stakeholders in home care to get a whole and comprehensive picture of situations that might improve or hinder the success of home care provision in rural Namibia. They felt that assessment/diagnosis should be done by identifying the community's own problems/abilities and assessing the patient's abilities before discharge, expressed as "Ask someone in your family who can help." It is their responsibility to identify where they can get help in the case of home care provision: "One can contact the headman and explain your problem to him ... and the headman will call a meeting so that one can explain his/her problems to those attending the meeting."

Other expectations included the idea that health facilities should have a pre-discharge programme during which education and orientation towards home care provision is given, either by means of video instruction in the wards and/or through group discussion. The following quotes support this interpretation: "My mother was taught and shown how to do exercise on me to prevent contraction formation and to turn me regularly to prevent bedsores development"; and "I was told nothing, only that we were discharged."

Health facility staff should conduct home visits and consult with the families before the patient is discharged in order to assess the abilities and skills of the families to continue with care at home. This was expressed as: "Before discharge, health workers should do home visits and consult with the family ... on the following: Are they able to continue with care at home, how will they provide the home care, and who will provide the care at home in the family?"

Stakeholders at the health facility and on village level are expected to identify the capacity at home as well as the availability of support systems for home care provision within the family. They are expected to analyse the possible support systems available to the family and the patient. This view was expressed as "We ask them if they do not have a family member or a relative who can assist them" and "Before discharge of a patient, assessment of the home situation needs to be done and determine if patients will be in good care of ... will be in good hands and home visits should be conducted before patient is discharged and this is not done at all."

Most of the home care providers expect the community in general to guide care provision, as they believe that home care is not a new thing. In any community there are people that have knowledge of and have experience of home care. This was expressed as "The community can guide you" and "People will guide you on the washing of the patients and food preparation."

Before the discharge of a patient, health workers (the professionals) are expected to assess the financial capacity of the families, as some families are too poor to continue with home care. Many families cannot afford basic needs, such as food, transport and bedding, as expressed "We have reported needy cases to our councillor's office for help (people in dire poverty)"; "Some families do help but some are very poor"; and
"Pensioners - some of them are very poor and the care they receive is not adequate."

To ensure that home care is provided on a continuum, it is expected that communication and collaboration levels between home care providers should be assessed, as this is thought to be essential in the provision of home care. Communication and collaboration between stakeholders in home care is necessary to ensure continuity of care and follow-up for patients. The following was said: "Health workers should consult with the family member who is with the patient ..."; "Patients and care providers should be informed to help each other"; "My family was not told anything"; and "It would be good to follow them to their homes... only if we had time to see what they do after they have left us and the young girls, before discharge, we must see their guardians and inform them how they should take care of them and support them."

Furthermore, they expect that training needs related to home care provision are determined, so that they are informed and oriented on home care activities before patients are discharged. This could also be done during home visits for persons receiving care in home situations, e.g. the establishment and implementation of pre-discharge programmes at health facilities by showing videos, conducting demonstrations and performing dramas that display home care activities. These actions would alleviate fear and shock when told that one is discharged and has to continue with care at home. This was supported by the following statements: "Educate the community on how to provide home care"; "... if I leave my husband, no one will care for him, but they should teach us how to prevent infection and I was told nothing, only that we were discharged" (very angry and with emphasis).

\section{Planning of home care provision}

In planning home care provision, expectations are related to the planning of activities that enable home care providers to conduct home care as expected. Some of these issues are mentioned below.

It is expected that home care providers are able to identify and select the appropriate support system required (depending on the case), be this support from the community, the family and/ or the government. The support system chosen should be able to alleviate a specific need in a specific home care situation. This view was expressed as "Family should ask for it (i.e. help) from the church and community members"; "They should notify the headman that they have a sick person at home" and "Church should provide spiritual counselling." As in any new programme, home care providers must set goals and priorities at all levels of the programme, i.e. in health facilities and at family/community level. Both levels of home care providers have a role to play and need to be involved in this process of goal and priority setting.

As this is a new programme, home care providers expect that planning is done to address the elimination of poverty. They expect that poverty be taken into account when dealing with home care, as this will have an effect on the quality of care provided in a home situation. This was expressed as follows: "People need blankets and clothes, but mostly food"; "I have nothing. They took all our bed and linen when my husband 
died"; "Ask someone in your family who can help"; "Poverty is a problem"; "Some families do help but some are very poor"; and "People are poor and have no blankets for the sick."

Stakeholders expect that the health facilities should plan to establish pre-discharge programmes to prepare families and individuals for home care before discharge. This view was expressed by almost everybody in this study. It is expected from knowledgeable people at village level and from health facilities to explain the health status of the patient to him/her and to guide them on home care and the importance of followup, as well as on the home visits. Patients are sometimes discharged without being made aware of the details of their illnesses, as expressed: "Educate the community on how to provide/give home care'; "I was not told about my condition that I am permanently disabled" (paraplegic); "I thought they would tell me about his illness"; "People should be told if they have $A I D S$, so that they can protect themselves and others"; "It is always good if the family are informed about the patient's condition to enable them to assist him/her as expected"; "Health workers and community health workers must teach the community members on what is home-based care, what should be done when caring for a patient at home"; and "Health workers must do pre-discharge assessment."

Each case in a home care situation is unique. It is, however, expected of the stakeholders to identify and select the appropriate support systems available to them, especially at village level. They should know their environment and be aware of the existing support systems available, as stated: "Inform the headman and women to facilitate the assistance needed"; "Family should ask for it (help) from the church and community members"; "Utilise women and youth groups"; "Family members to act as nurses and ... "; "Refer to NAMTA if they ask for food"; and "We expect the headman to know and visit patients in their village."

It is expected of the professionals to plan home care with the families, to establish referral opportunities and to determine follow-up strategies. Families need to determine how the patient will get to follow-up treatment, as well as who will assist him/her during the treatment. This would ensure continuous care of the patient, as was expressed: "We refer them to clinics near them, usually to go after a week to see and evaluate how the wound is progressing with salt and warm water ... the episiotomy"; "We tell them to come for follow-up counselling"; "They should be well-guided as they are the care givers for the rest of the day"; "... do pre-discharge assessment"; "Ask them the nearest clinic to their village to enable them to get their treatment from there" and "No, there is no communication about these referrals."

Stakeholders expressed a need for the implementation of a programme to educate and train them in the basic principles of home care provision, especially at village level. Any new programme should contain an introduction that prepares them for the tasks awaiting them. This need was expressed as: "This needs education in general, even at schools for children to help with home care"; "Tell them the importance of treatment completion and tell them not to skip any follow-ups"; and "We train home care givers at village and hospital levels."
Home care providers expect planning to be done to establish communication and collaboration channels between the stakeholders in home care provision. This is necessary to ensure the provision of care on a continuum. Such sentiments were expressed as follows: "We refer to clinics near them ...." Although health care providers consult each other in some cases, this does not always happen, as stated, "No, there is no communication about these referrals", when referring to patients from the wards sent to the HIV/AIDS counselling office at Oshakati State Hospital, or "From this office we did not contact the headman regarding patients at home as yet"; "We do not call on social workers, we do not even involve them in defaulters tracing"; and "Some community members do understand and appreciate all the efforts - these are the people who even refer and report houses where there are patients who are sick or receiving home care."

Home care providers expect a plan to be developed to motivate and empower communities to enable them to contribute to home care provision in their midst/villages. This is necessary so that people who are discharged from the health facilities should not feel as if they are being "dumped" and that the state does not care about them. Plans should be devised to inform communities why there is a shift in responsibility in the caring of patients, i.e. from health facilities to the home and community care. This need was expressed as: "People need to be motivated and empowered to be able to deal with the care at home"; "We train home care givers at home and hospital levels"; "We tell them about their illness, the long-term treatment they will receive from now on and ways to take medicine as prescribed." Strategies should be identified and a choice made by both players on the best strategy to use for a specific case, e.g. meetings, radio talks, drama performances, etc.

Home care providers expect plans to be made to guide them in self-help activities, be this for home care and/or for income generation activities, so that dependency among individuals and families can be avoided. They state: "NAMTA teach patients hand-work, especially women ... to weave traditional baskets and teach them to use sewing machines. These patients are allowed to sell their products and get some income from this."

\section{Implementation}

Expectations on implementation are related to the activities and tasks that need to be carried out during home care provision and are discussed below.

Almost $95 \%$ of all Namibians are Christians. Home care providers therefore expect to receive spiritual support, either from the church and/or from the community in general. This was expressed as: "Ask the community to pray for your patient"; "Organise church services for the patients at home"; "I get visits from the social workers and church members ... this makes me feel happy" and "Church groups should visit patients at homes to sing and care for them, especially on Sundays."

Family and community members are expected to mobilise all resources at their disposal to contribute to and ensure quality home care provision. Community members are expected to assist other members of their communities, as was expressed: 
"Utilise women and youth groups"; Villagers should help or assist with patient care in homes"; "Community members to assist their people at village levels"; "Churches must help with orphans by giving food and clothing"; "People need to be motivated and empowered to be able to deal with the care at home" and "Community ... they cannot just rely on health workers ... they also have a responsibility to take care of their people."

Home care providers want information to be shared by means of meetings conducted by the headman and/or other resourceful persons in the community. The headman at village level should hold such meetings. This view was expressed as: "Headman should call meetings so that one (with a patient being cared for at home) can explain his/her problems and the community can guide you" and "Inform the headman and women to facilitate the assistance needed."

Home care providers expect people and families receiving and providing home care to "open up", as this will facilitate the necessary help and assistance. They expect families to be frank about the patients for which they are caring at home. They should encourage people to visit those who are being cared for at home. This will help them feel that they are part of the community and that they are not isolated, as was stated: "The patient should not to be hidden from the public" and "Encourage visitors and discussions with the patient."

Home care providers want to be visited by the public, families and the health workers, as expressed: "I need them to visit me (referring to friends and health workers), but some are afraid of me"; "I get visits from a social worker and church members ... this makes me feel happy"; "Church groups should visit patients at homes to sing and care for them, especially on Sundays" and "We visit homes both in rural and urban areas."

Other expectations include the ability to provide palliative care for the sick person at home, i.e. the provision of basic nursing care such as daily washing and feeding of patients at home "Keep caring for the patient by washing him" and "People will guide you on the washing and food preparation." To ensure that home care providers provide quality home care, they expect in return to be guided through training by those who are experienced, especially health professionals at health facilities, as well as by knowledgeable people at community level. This was expressed as follows: "Educate the community on how to provide/give home care"; "We give information on personal hygiene - self-washing, clean clothing, changing of sanitary pads to prevent infection and bad smells"; "Go out and conduct community training at village levels" (referring to health workers) and "Educate patients and those close to them."

To be able to cope, home care providers want to be taught new coping and problem solving skills. Depending on each case and after a thorough assessment, alternative methods should be applied and relief care providers can be recruited. Home care providers are expected to copy coping strategies from others who have succeeded in similar situations, e.g. "I feel there should be a centre established where these patients getting home care could come together during the day ... to share their experiences"; "Some people are very lonely in their homes and have not even a radio to listen to ... a centre should be established as a day care centre for them to spend a day."

Home care providers and receivers expect that home care providers should attend to the nutritional needs of the sick person. It is expected of them to ensure that the sick person gets the nutrition he needs or asks and to appreciate the importance of providing a balanced diet to a patient, in order to boost the immune system and improve wound healing. This, however, requires that food, as well as the necessary knowledge and skills for the preparation of nutritional food, are available. Guidance and assistance in home care provision are needed from all players in this regard. Various statements were made like "Cook food which he/she needs"; "We tell them to follow a healthy diet"; "We tell them to follow a healthy diet, especially using the local food such as eggs, apples, berries and oombe" and "Tell them the importance of nutrition."

Home care providers expect that when providing home care, the support systems for care at both national and community levels are mobilised. When given all the skills, it is also the duty of the community to mobilise all resources available to them and to utilise these resources to improve the care provided in the home environment. This was view was expressed as follows: "Utilise women and youth groups"; "Churches must help with orphans by giving food and clothing" and "We have reported needy cases to our councillor's office for help" (i.e. people in dire poverty).

To ensure quality care on a continuum, some kind of communication lines and collaboration patterns between home care providers should be established and utilised. Statements like "Family should be informed as care givers to come to hospital to be given information on the care at home"; "Patients we see some are referred to us, others are self-referrals" and "From this office we did not contact the headman regarding patients at homes as yet", support this view.

Most home care providers expected that patients and care providers be informed about the patient's illness and the care that is needed at home. They believe that unless they are informed, the care required might not always be provided and family members will not fully understand why a patient is behaving in a particular way. With proper information and guidance, the family is expected to handle the issue of confidentiality with great care and an open mind so as not to harm their patient. These views were expressed as: "I expect to be informed on the illness, especially AIDS ... this will spread the infections"; "My family was not told anything ... my family is not happy that I am not working heavy work"; and "It is always good if the family are informed about the patients' conditions to enable them to assist him/her as expected."

It is expected from health professionals, village counsellors and the community's own resource persons to conduct training in home care at all levels, i.e. village and hospital level. This was stated as: "We give them information on personal hygiene, i.e. self-washing, clothing, changing of sanitary pads to prevent infections and bad smells"; "We train home care givers at village and hospital levels, we are still looking for our own place where to work from for training"; "Sometimes we call family members to explain the situation of the patient 
to them"; "Go out and conduct training at village levels" and "We are required to inform our patient by law ... educate the patient and those close to them and prior discharge home visits should be done."

In order to facilitate the care given by the community health workers and to promote recognition, community leaders and the community health workers want to be issued with uniforms and home care kits and to be provided with bicycles as a means of transport. They want these people to be recognised and their work to be appreciated by the public, as expressed: "Listen to the volunteers' problems, i.e. give them bicycles, home care kits, transport and uniforms."

\section{Evaluation}

Evaluation deals with the ultimate outputs of the whole programme as related to the aims and objectives of home care provision.

It an expectation of home care providers that, after discharge from the health facility, having all the skills and resources needed at hand and with the support of all players, they will be in a position to provide care independently in their home environments. This implies that families will be self-reliant in terms of care at home for their patients, as they will know when and whom to call upon, should any emergency arise. They will have the knowledge and skills to provide home care and will utilise all available resources to sustain such a programme.

It is an expectation of the stakeholders that after being well prepared and trained for the caring of individuals at home, they will actually carry out some of these activities on their own, in the absence of health professionals. This was expressed as "This will enable one to protect selffrom self-infection."

It is an expectation of the home care providers that, after the necessary training and guidance, they will be skilled to provide quality home care and will even be creative enough to improvise in those cases where resources are inadequate. This would improve the patients' comfort and patients will be satisfied with the care provided to them. The terminally ill can therefore die with dignity, knowing that their caregivers had tried very hard to make them comfortable, even in difficult situations.

To avoid burnout and to deal with problems, community volunteers and those in the home environment need coping and problem solving mechanisms. They need to be equipped to initiate activities to alleviate stress in themselves. Village counsellors at all villages will be available to assist with supportive counselling and consultation.

Ultimately, the home care providers want their patients to be satisfied with the care and support provided to them and to be comfortable with the whole caring process in their home environment. The community will understand the reasons for the shift from being cared for at a health facility to being cared for in a home environment, rather than feel abandoned by the state.

\section{Discussion of the results}

From the empirical data, it appears that the care providers of home care are generally family members, friends and neighbours, as was also found in Japan and among the Alaska Natives (Jackson et al, 1995). The data also indicates that most caregivers live in dire poverty and cannot afford to pay for food and transport. This supports the findings of McLaren \& Mdunyerwa's in KwaZulu-Natal in 1999.

Structures are not always available to those who render home care, as was revealed by this study. This is similar to what was found in Italy and in Zimbabwe (Marrazi et al, 1994; Hanse et al, 1998). Transport and health services are not always accessible, as was found in Namibia (Jackson et al, 1995). Home care providers expected to be provided with water, food, clothing, blankets and protective materials. These problems were also indicated in studies conducted in Botswana, Zambia and Zimbabwe (Van Praag, E; Schweyen, V; Ng'weshemi, J. 1997; MacNeil, 1996; Mares et al, 2000).

The study also shows that general follow-up and referral of patients receiving home care needs attention (Nnamdi, 1995; van Praag et al, 1997). Unlike in the USA, home care agencies and hospices are non-existent in rural Namibia. These agencies could offer skilled nursing, physical/occupational/speech therapy, nutritional and respiratory services (Hohl, 1994:52).

Although home visits by health professionals is a strategy to provide effective home care, many countries may not be able to afford to sustain this system, as was found by Stuart in KwaZulu (1994:10-11). Namibia is no exception in this regard. In that study, Stuart found that training, expertise, medication, food, counselling and welfare must be provided to the families. The Roman Catholic Church's response to the HIV/AIDS pandemic has played an important role in this type of support (Vitillo, 1993:18-19).

Hanse et al (1998:751-9) suggest that when carrying out a needs assessment, an estimation of the costs incurred by the family should be assessed. These costs may include the actual costs of food and all materials bought and can be used for medicines and transport, as well as for the extra cost of the relatives' visits, bearing in mind that culturally, visitors must be shown hospitality and this includes providing food and drinks.

In Tanzania it was found that counselling services were more needed by the patients and their families, above and beyond simple clinical care. To be able to reach all families, health workers trained community volunteers in basic health care, HIV education and counselling skills in each village. These volunteers provided all types of care to those patients with which they were able to deal and referred problem cases that they were unable to handle themselves to the health professionals. Community members were encouraged and became involved by pooling their resources to help meet the basic survival needs of other members of their community who were chronically ill at home (Anonymous, 1993:2). Networking, coordination and collaboration between health care providers were some of the strategies identified in the findings. These clearly link with Cameron, Shepard and Mulwa (1996), who stated that to provide quality home care for chronically ill pa- 
tients at home, such care should be linked through networking and co-ordination so that active referral for comprehensive care can be made.

The outcome of home care should be patient satisfaction, selfhelp activity in health matters and increased knowledge and skill among the home care providers and receivers. This confirms the findings of Schietinger et al (1993:33-53), where families and patients were interviewed on how they felt about the services provided by the community/village volunteers at home. The families responded positively to the support provided by those volunteers. Sometimes technical support is all that is required for those in home care environments, but such support is not always available in most cases (Stegling, 2000:10; Stuart.1994:10; Nnamdi, 1995).

\section{Conclusion and \\ recommendations}

In the final analysis, there seems to be no conducive conditions for home care provision in rural Namibia. Basic structures are lacking. Community education seems to be inadequate. There is therefore no way that we can speak of quality home care without having the basic structures for home care in place. Unless these structures are put in place, one cannot start developing guidelines to facilitate quality home care in rural Namibia.

Stakeholders in rural Namibia still seem to have dependency tendencies and expect all resources and services to be provided by someone else, be it the government, the church, the headman and/or any other non-governmental agencies. There is a need for empowerment and capacity building in the community and awareness must be created of the responsibility of the community in dealing with home care provision. All these observations are linked to community development and community participation and involvement in health care provision. In conclusion, it is the conviction of this researcher that if proper preparation were done in terms of community mobilisation, capacity building and empowerment, the stakeholders in home care would become aware, appreciate the value of selfcare, and develop self-confidence in this noble activity.

\section{References}

ANONYMOUS 1993: Caring for people with HIV/AIDS. Time to Act. World Health Day:2.

BRINK, HI 1996: Fundamentals of research methodology for health care professionals. Cape Town: Juta \& Company Ltd.

CAMERON, C; SHEPARD, D; \& MULWA, J 1996: Caring for persons with AIDS (PWA) in Botswana:is home-based care the answer? AIDS in the world II: Global dimensions, social roots, and responses:405 -7 .

DE VOS, AS; STRYDOM, H; FOUCHE, CB \& POGGENPOEL, MJL 1998: Research at grassroots:A primer for the caring profession. Academia: Pretoria: Van Schaik:\& Schurink.

DENOSA, 1998: Ethical nursing standards. Pretoria, RSA.
HANSE, K; WOELK, G; JACKSON, H; KERKHOEVEN, R; MANJONJORI, N; MARAMBA, P; MUTAMBIRWA, J; NDIMANDE, E \& VERA, E 1998: The cost of home-based care for HIV/AIDS patients in Zimbabwe. AIDS Care. Vol 10 (6):751-759.

IYAMBO, N 1990: Towards achieving health for all Namibian: A policy statement. MOHSS - Windhoek: Namibia.

JACKSON, H \& KERKHOVEN, R 1995: Developing AIDS care in Zimbabwe: A case for residential community centres? AIDS Care. Vol 7 (5):663-73.

KANE, RA; KANE, RL \& EUSTINE, NN 1994: Perspectives on home care quality: Health Care Financing Review. Vol 16, 69 -89 .

KANE, RA; KANE, RL; ILLSTON, LH \& EUSTINE, NN 1994: Perspectives on home care quality. Health Care. Vol 16 (1):6987.

KATIYO, TB 1997: Home based care in Zimbabwe. Official Journal of the Zimbabwe Nurses Association. May; ZINA.

KRUEGER, RA 1994: Focus Groups. London: Sage Publications.

KUBATO, M; BABAZONO, A \& AAYAMA, H 2000: Women's anxiety in old age and long - term care provision for the elderly. Acta Med Okovama. Vol 54 (2):75 - 83.

LINCOLN YS \& GUBA, EG 1985: Naturalistic Inquiry. London: Sage Publications.

MACNEIL, JM. 1996: Use of culture theory with Baganda women as AIDS caregivers. Journal of Transcultural Nursing. Vol 7(2):14-20.

MARRAZI, MC; PALOMBI,L; MANCINELLIS,S; LIOTTA, G \& PANA, A 1994: Care requirements of people with HIV/ AIDS in Rome: Non-hospital services. AIDS Care. Vol 6(1):95104.

MARES, A \& MCGUIRE, J 2000: Reducing psychiatric hospitalisation among mentally ill veterans living in board - and care homes. Psvchiatric Services. Vol 51 (7):914 - 21.

MCLAREN, P \& MDUNYERWA, M 1999: Report on homebased care services and training in health region $\mathrm{B}, \mathrm{KwaZulu}$, Natal.

MERRIAM, SB 1998: Case study in education: A qualitative approach. San Francisco: Jossey Bass Publishers.

MOHSS/NCAP 1990: The Health Policy Statement of the Ministry Of Health and Social Services. Windhoek. Namibia.

MOHSS/NCAP 1996: Final Review of the Medium Term Plan 1 MOHSS, Windhoek:Namibia.

MOHSS/NCAP 1998: Epidemiological Report on HIV/AIDS for the year 1997. European Commission Support. Windhoek, Namibia. 
MOUTON J 1996: Understanding social research. Academia: Pretoria: J.L. van Schaik.

NBS (NAMIBIA BROADCASTING CORPORATION, RADIOSERVICES) NEWS. DECEMBER, 1:1996.

NBS (NAMIBIA BROADCASTING CORPORATION, RADIO SERVICES) NEWS. OCTOBER, 10:1996.

NBS (NAMIBIA BROADCASTING CORPORATION, RADIO SERVICES) NEWS. MAY, 8:1997.

NBS (NAMIBIA BROADCASTING CORPORATION, RADIO SERVICES) APRIL, 11: 1998.

NNAMDI RU 1995: Report of the home-based care consultancy mission in Namibia; Okagobue, WHO/GPA.

PARAHOO, K 1997: Nursing research: Principles, process and issues. Houndmills Hampshire: MacMillan Press Ltd. RG2 6 x S.

SCHIETINGER, H; ALMEDAL, C; BIZIMUNGU, NM; RURUKU, KJ; JACQUELINE, RK \& RAVN, BL 1993: Teaching Rwandan families to care for people with AIDS at home. Hospice Journal. Vol 9 (1):33-53

SOLDAM, K; ABDOOL KARIM, W \& ABDOOL KARIM, SS 1993: Home-based care for HIV/AIDS: Evaluation of the KwaZulu pilot project. Durban: Medical Research Council.

STEGLING, C 2000: Current challenges of HIV/AIDS in Botswana: Department of Sociology; University of Botswana.

STUART, J 1994: Evaluation of home-based care in KwaZulu. AIDS Bulletin. Vol 3(1):10-11.

THE NAMIBIAN: December 1997.

THOMSON, K 1996: Capacity Development in the environment: A practical aid to sustainable development? EC Aid and Sustainable Development Briefing Paper. No. 12.

VAN PRAAG, E; SCHWEYEN, V \& NG'WESHEMI,J 1997: Caring and counselling. HIV prevention and AIDS care in Africa. 307-24.

VITILLO, RJ 1993: Catholic Church's response to the pandemic of HIV/AIDS. Children Worldwide. Vol 20 (2-3):18-9.

WHITESIDE, A 1997: How HIV/AIDS impacts on the health sector: Special report 1997 - AIDS Analvsis Africa. Vol 7(2) April. 